\title{
COUNTRY-SPECIFIC DETERMINANTS OF INTRA-INDUSTRY TRADE IN PHARMACEUTICALS: THE CASE OF POLAND AND ITS EUROPEAN UNION PARTNERS
}

\author{
Justyna Łapińska, Jana Meluzínová, Jiří Uhman
}

\section{Introduction}

Pharmaceuticals are chemical and biological substances produced by the pharmaceutical industry, used in therapies and prevention of various diseases. They cover an extremely wide range of products, ranging from simple medicinal preparations, to extremely advanced technological specifics. Similar to food, pharmaceutical products are believed to be one of the most important needs of human beings. They have a significant impact on their health, often support and extend their lives. Due to their specific properties and healthcare function of pharmaceuticals, they are contained in the category of basic products and their significance is appreciated not only by buyers (patients) but also by authorities in most countries. That is why in many countries special attention is paid to the development of production and trade in pharmaceutical products. The special importance of the pharmaceutical industry was also emphasized in a European Commission document, which indicated that it is a strategic branch of Europe's industry (European Commission, 2014).

The important role of international trade in pharmaceutical products is the resultant of many factors determining the situation on the global pharmaceutical market. The major factors include as follows:

- restrictive legal provisions; they concern every stage of the production and distribution chain, from the synthesis of active substances to the dispensing of the drug to the patient;

- limited possibility of transferring unique technologies within the pharmaceutical sector, resulting mainly from huge costs; the development and implementation of new effective medicines for production is not only very costly but also time-consuming;

- patent protection of many pharmaceutical products; global pharmaceutical concerns effectively protect their production, making it impossible for other producers with generic equivalents of patented drugs to enter the market;

- aging societies and an increase in the problem of civilization diseases, especially in developed countries and the related increase in the demand for medicines and medical products.

The largest part of world trade is intraindustry trade. It occurs when countries simultaneously export and import products belonging to the same industry branch (commodity group). It develops particularly well in industrialized countries in the scope of processed products, especially those that are available in many versions or variants (Łapińska, 2016; Cieślik \& Wincenciak, 2018). This category also includes medicines and other products delivered to the market by the pharmaceutical industry. Many factors determine the commencing and intensity of intra-industry trade. The creators of theoretical models of intra-industry trade perceive the reasons for the development of this type of exchange in the existence of a specific, usually imperfectly competitive market structure, where various types of products are traded. The nature of the production technique used is also significant, characterized by increasing economies of scale. However, the diversity of products and the presence of economies of 
scale are only a prerequisite for the emergence of intra-industry trade flows. A range of factors determines whether intra-industry trade between countries will be initiated and then developed. These factors reflect the specifics of trading countries and characteristics of markets, products and industries (branches) in which the exchange takes place.

The existing subject literature lacks empirical findings on the factors determining intra-industry trade in pharmaceutical products, especially in European Union trade. The few publications on the determinants of intraindustry trade in this extremely important group of products concern the Middle East countries (see Yusefzadeh et al., 2015; Aghlmand et al., 2018). Therefore, this study is an attempt to fill part of the existing research gap in this area.

The purpose of this study is to identify the country-specific determinants impacting the intensity of intra-industry trade within Poland's trade turnover with European Union countries in pharmaceutical products.

\section{Country-Specific Determinants of Intra-Industry Trade - Literature Review}

The specificity of intra-industry trade means that so far it has not been possible to develop one model that would explain the existence of all streams of this type of exchange. This results in some difficulties in identifying the factors determining the development of intraindustry trade. Individual models (see e.g., Krugman, 1979; Brander, 1981; Davis, 1995) explain the existence of only some specific intra-industry trade streams. Depending on the adopted assumptions of the model construction (e.g., the structure of the market on which the exchange is being carried out, the type of goods being subject to exchange), different conclusions can be drawn as to the prospects for the development of two-way trade. It causes that the set of determinants of intra-industry trade, referring both to the characteristics of economies participating in the exchange, and to the characteristics of industries and products subject to exchange is quite wide. Among the researchers of intraindustry trade, there is, however, a greater consensus on macroeconomic determinants of the development of intra-industry trade, i.e., country-specific determinants rather than industry-specific determinants.
Previous theoretical and empirical studies confirm that the determinant that is conducive to the development of intra-industry trade is the high level of gross domestic product per capita. The impact of GDP per capita on the intensity of intra-industry trade can be interpreted in two ways - from the supply and demand sides (Czarny, 2002). First of all, highly developed economies are characterized by a higher level of innovation and have a better developed processing industry. This facilitates the introduction and development of the production of substitute goods with a significant degree of differentiation, which, in turn, facilitates the development of two-way trade. Secondly, high income consumers are more likely to buy diversified, highly processed products which, in turn, facilitate the development of the exchange of similar products belonging to the same branch. The importance of high GDP per capita in increasing the intensity of intra-industry trade is also confirmed by Thorpe and Zhang (2005), Dalgin (2010), Phan and Jeong (2014).

Small differences between GDP per capita of trading countries constitute another factor supporting the development of intraindustry trade. They can be indicative of similar consumer preferences of buyers from both countries. Such an interpretation refers to the concept of similarity created by Linder (1961), according to which the intensity and structure of trade depend mainly on the degree of similarity between countries. The importance of this determinant in increasing the intensity of intraindustry exchange is confirmed by Loertscher and Wolter (1980), Thorpe and Zhang (2005), Łapińska (2014).

A significant factor determining the intensity of intra-industry trade is the size of economies that trade with each other. They are usually measured by the size of their GDP. The size of economies is recognized as a key determinant in the development of turnover in the gravity models of trade (see, for example, Anderson, 1979; Bergstrand, 1985; Pietrzak \& Łapińska, 2014, 2015; Cieślik \& Michałek, 2018; Szczepaniak, 2018). The bigger the trading partners' economies, the more intensive trade exchange, including intra-industry trade. This is confirmed by numerous empirical studies (see, for instance: Caetano \& Galego, 2007; Onogwu, 2013; Jámbor, 2014; Aghlmand et al., 2018).

The size of the economy is related to the possibility of developing production 
characterized by increasing economies of scale, which in the light of the theory of intraindustry trade are one of the key determinants encouraging countries to specialize in intraindustry and two-way trade. The size of GDP is also considered to be a measure of the development of production of diverse goods and an important factor affecting the level of international competitiveness of countries (Cheba \& Szopik-Depczyńska, 2017). Higher GDP is then tantamount to having a large capital stock and developed financial markets, which provide financial support for capitalintensive, technologically advanced industries (Kocmanová, Dohnal, \& Meluzín, 2011; Meluzín \& Zinecker, 2014; Meluzín et al., 2017). This, in turn, enables the development of the processing industry manufacturing diverse goods.

The factor supporting the development of intra-industry trade is also small differences in the size of the trading countries' economies, expressed as the differences in the levels of GDP of trading partners. This determinant is related to Helpman's theorem (1987), which showed that bilateral trade between countries is directly proportional to the product of their gross domestic products. He confirmed the truth of his claim with reference to highly developed countries. Empirical tests of Helpman's theorem were also carried out by other researchers (see, for example, Hummels \& Levinsohn, 1995; Okubo, 2007). The results obtained by them indicate the existence of a negative correlation between intra-industry trade and large differences in the size of countries that trade with each other. There are, however, some empirical studies that do not confirm this relationship. According to Markusen and Vanables (1996), comparable sizes of economies are not necessarily conducive to the development of intra-industry trade. Under certain conditions, intra-industry trade may be replaced by mutual direct investments (Fukao, Ishido, \& Ito, 2003; Nazarczuk \& Umiński, 2018).

Other factors determining the level of intraindustry trade between countries is a large share of goods processed in mutual trade and a significant intensity of trade contacts between trading partners. Ekanayake (2001) and Łapińska (2016) show that they significantly support the development of intra-industry trade. Empirical research (see, for instance, Leitão, 2011; Łapińska, 2014) also shows that imbalance of trading countries' trade balance has an adverse effect on the intensity of intraindustry trade. If trade exchange between two countries is not balanced, then the intensity of intra-industry trade cannot reach the maximum value.

A factor significantly affecting the degree of intensity of trade between countries is also the geographical distance that separates the trading partners. A considerable distance between two trading countries results in an increase in transaction costs, mainly due to the cost of transport and insurance of goods. It is therefore a factor limiting the development of trade, including intra-industry trade (Leitão \& Shahbaz, 2012; Phan \& Jeong, 2014; Łapińska, 2016).

The factor supporting the development of intra-industry trade related to geographical proximity is having a common border with a trading partner (Ekanayake, 2001). This dependence is mainly due to the possibility of using the advantages related to the location of production. The intensification of intraindustry trade is also strengthened by cultural community, similar language, historical and political ties (Czarny, 2002). However, Matthews (1998) argues that these factors lose their importance as the economic integration progresses.

Intra-industry trade becomes more intense where economies begin to open up. The most common measure of the protection of the internal market in this context is the nominal level of customs duties. The negative relationship between the size of trade barriers and the intensity of intra-industry trade was first noticed by Balassa (1966). The existence of this dependence was confirmed later in other studies carried out by, for instance, Bergstrand (1990), Sharma (2004), Foster and Stehrer (2011), and Łapińska (2015). The opening of economies is connected with another important factor supporting intra-industry trade, namely integration processes. The importance of economic integration in increasing the intensity of intra-industry trade is associated not only with the reduction of restrictions on trade but is also due to the fact that the integration group usually includes countries with a similar level of economic development. The results of empirical research (see, among others: Sharma, 2004; Wakasugi, 2007; Foster \& Stehrer, 2011; Łapińska, 2015) prove that in the conditions 
of imperfections of competition and product differentiation, integration processes favour the development of intra-industry trade.

In empirical studies, attempts are made to verify other factors, such as, for example, foreign direct investment (Xing, 2007; Ambroziak, 2016). The impact of FDI on the development of intra-industry trade can be positive, providing it contributes to the modernization of the economy, industrial development and the production of diverse goods, or negative, if it is a substitute for trade with foreign countries.

\section{Intensity of Intra-Industry Trade in Pharmaceuticals between Poland and European Union Countries}

In most cases, the Grubel-Lloyd index is used in empirical research to measure the intensity of intra-industry trade and it is calculated according to the following formula (Grubel \& Lloyd, 1975):

$$
G L_{i}=\frac{\left(X_{i}+M_{i}\right)-\left|X_{i}-M_{i}\right|}{\left(X_{i}+M_{i}\right)}=1-\frac{\left|X_{i}-M_{i}\right|}{\left(X_{i}+M_{i}\right)}
$$

where $X_{i}$ - the value of exports of the industry $i$; $M_{i}$ - the value of imports of the industry $i$.

The above indicator takes values from the interval [0;1]. The higher the $G L_{i}$ indicator value, the more intense intra-industry trade. The maximum value is achieved if the turnover of a given industry (branch) is balanced $\left(X_{i}=M_{i}\right)$; Then, the entire trade volume within this branch is intra-industry like. If, however, branches do not export or import goods at all $\left(X_{i}=0\right.$ or $\left.M_{i}=0\right)$, the $G L_{i}$ index takes the value equal to zero, which means that no intra-industry trade occurs.

Examining the intensity of intra-industry trade with a specific trading partner requires the use of a bilateral index:

$$
\begin{aligned}
& G L_{i j}=\frac{\left(X_{i j}+M_{i j}\right)-\left|X_{i j}-M_{i j}\right|}{\left(X_{i j}+M_{i j}\right)}= \\
& =1-\frac{\left|X_{i j}-M_{i j}\right|}{\left(X_{i j}+M_{i j}\right)^{\prime}}
\end{aligned}
$$

where $X_{i j}$ - the value of exports to the country of the trading partner $j$ of goods belonging to the industry $i ; M_{i j}$ - the value of imports to the country of the trading partner $j$ of goods belonging to the industry $i$.
An aggregated measure that shows the intensity of intra-industry trade in all countries or a group of countries is obtained by calculating the weighted average value of indices for individual countries $\left(G L_{i j}\right)$. The weights of each of the countries in total turnover in specific goods or groups of goods are considered to be weights.

Intensity indicators for Poland's intra-industry trade in pharmaceutical products with individual EU countries in 2004-2016 are presented in Tab. 1. They were calculated for three-digit groups of goods separated according to the Standard International Trade Classification. The groups were: 541 - medicinal and pharmaceutical products (other than medicaments of group 542 ) and 542 - medicaments (including veterinary medicaments). The presented data show that in the years 2004-2016 there was an increase in the intensity of intra-industry trade in pharmaceuticals with the majority of EU countries. The intra-industry trade with countries that were members of the Community before its enlargement in 2004 (EU-15) was particularly well developed.

The greatest increase in the intensity of intra-industry trade was recorded in trade with Denmark. In 2004, Polish-Danish intra-industry trade in pharmaceutical products practically did not exist, the Grubel-Lloyd index was only 0.034 . However, in the last year covered by the analysis, intra-industry trade was already the dominant form of trade with Denmark $\left(G L_{D K}=0.883\right)$. A significant increase in the intra-industry trade index was also recorded in trade with Portugal, Spain, and Italy (see Tab. 1). In the case of several trading partners, the two-way trade intensity indices decreased over the period considered. However, these countries did not belong to the group of Poland's most important EU trade partners in pharmaceutical products. In 2016, their share in Poland's trade in pharmaceutical products amounted only $6.2 \%$, which did not significantly affect the development of the aggregate Grubel-Lloyd index for pharmaceuticals, which increased from 0.125, in 2004 to 0.417 , in 2016 (see Fig. 1).

In order to identify the factors, which determine Poland's intra-industry trade with European Union countries, an econometric model for panel data was constructed. The values of the bilateral Grubel-Lloyd index were assumed to be the explained variable. 


\section{Tab. 1: \\ Intensity of intra-industry trade between Poland and European Union countries} in pharmaceutical products in the years 2004-2016

\begin{tabular}{|c|c|c|c|c|c|c|c|c|c|c|c|c|c|}
\hline Country & 2004 & 2005 & 2006 & 2007 & 2008 & 2009 & 2010 & 2011 & 2012 & 2013 & 2014 & 2015 & 2016 \\
\hline Austria & .004 & 0.010 & 0.234 & 0.139 & 0.154 & 0.277 & 0.255 & 0.204 & 0.200 & 0.109 & 0.086 & 0.123 & 0.128 \\
\hline Belgium & 0.003 & 0.004 & 0.013 & 0.018 & 0.005 & 0.021 & 0.045 & 0.034 & 0.034 & 0.062 & 0.090 & 0.105 & 0.131 \\
\hline Bulgaria & 0.636 & 0.174 & 0.095 & 0.281 & 0.108 & 0.183 & 0.270 & 0.603 & 0.786 & 0.949 & 0.850 & 0.883 & 0.674 \\
\hline Croatia & 0.514 & 0.375 & 0.549 & 0.733 & 0.957 & 0.942 & 0.387 & 0.314 & 0.605 & 0.380 & 0.681 & 0.573 & 0.616 \\
\hline Cyprus & 0.758 & 0.129 & 0.804 & 0.016 & 0.090 & 0.619 & 0.626 & 0.618 & 0.862 & 0.900 & 0.268 & 0.113 & 0.092 \\
\hline Czech Rep & 0.717 & 0.616 & 0.519 & 0.628 & 0.672 & 0.792 & 0.597 & 0.620 & 0.550 & 0.578 & 0.606 & 0.588 & 0.700 \\
\hline Denmark & 0.034 & 0.082 & 0.141 & 0.181 & 0.233 & 0.392 & 0.524 & 0.482 & 0.618 & 0.745 & 0.537 & 0.750 & 0.883 \\
\hline Estonia & 0.228 & 0.148 & 0.071 & 0.181 & 0.015 & 0.004 & 0.047 & 0.011 & 0.012 & 0.003 & 0.005 & 0.010 & 0.008 \\
\hline Finland & 0.952 & 0.300 & 0.329 & 0.247 & 0.661 & 0.929 & 0.680 & 0.796 & 0.371 & 0.312 & 0.337 & 0.447 & 0.515 \\
\hline France & 0.049 & 0.040 & 0.059 & 0.151 & 0.237 & 0.311 & 0.369 & 0.369 & 0.593 & 0.536 & 0.602 & 0.573 & 0.386 \\
\hline Germany & 0.164 & 0.130 & 0.218 & 0.338 & 0.369 & 0.462 & 0.525 & 0.535 & 0.546 & 0.566 & 0.473 & 0.417 & 0.489 \\
\hline Greece & 0.046 & 0.020 & 0.532 & 0.762 & 0.858 & 0.763 & 0.871 & 0.837 & 0.809 & 0.635 & 0.466 & 0.234 & 0.182 \\
\hline Hungary & 0.366 & 0.442 & 0.654 & 0.606 & 0.622 & 0.699 & 0.495 & 0.293 & 0.341 & 0.579 & 0.594 & 0.531 & 0.444 \\
\hline Ireland & 0.000 & 0.001 & 0.006 & 0.074 & 0.102 & 0.100 & 0.114 & 0.118 & 0.162 & 0.092 & 0.090 & 0.110 & 0.065 \\
\hline Italy & 0.239 & 0.160 & 0.269 & 0.439 & 0.490 & 0.733 & 0.839 & 0.840 & 0.779 & 0.796 & 0.793 & 0.854 & 0.832 \\
\hline Latvia & 0.419 & 0.213 & 0.137 & 0.090 & 0.120 & 0.167 & 0.089 & 0.191 & 0.112 & 0.066 & 0.154 & 0.174 & 0.227 \\
\hline Lithuania & 0.032 & 0.013 & 0.005 & 0.030 & 0.060 & 0.077 & 0.114 & 0.187 & 0.087 & 0.307 & 0.360 & 0.290 & 0.394 \\
\hline Luxembourg & 0.005 & 0.000 & 0.000 & 0.001 & 0.000 & 0.000 & 0.003 & 0.000 & 0.005 & 0.001 & 0.010 & 0.061 & 0.128 \\
\hline Malta & 0.000 & 0.062 & 0.217 & 0.036 & 0.073 & 0.285 & 0.272 & 0.158 & 0.284 & 0.372 & 0.136 & 0.081 & 0.109 \\
\hline Netherlands & 0.017 & 0.028 & 0.018 & 0.026 & 0.067 & 0.046 & 0.081 & 0.107 & 0.136 & 0.183 & 0.156 & 0.123 & 0.097 \\
\hline Portugal & 0.054 & 0.225 & 0.232 & 0.794 & 0.448 & 0.143 & 0189 & 0.293 & 0.364 & 0.398 & 0.565 & 0.680 & 0.772 \\
\hline Romania & 0.793 & 0.858 & 0.642 & 0.648 & 0.431 & 0.574 & 0.589 & 0.641 & 0.715 & 0.890 & 0.889 & 0.876 & 0.672 \\
\hline Slovakia & 0.341 & 0.741 & 0.902 & 0.841 & 0.632 & 0.627 & 0.456 & 0.473 & 0.714 & 0.651 & 0.293 & 0.298 & 0.269 \\
\hline Slovenia & 0.025 & 0.117 & 0.132 & 0.113 & 0.169 & 0.281 & 0.217 & 0.375 & 0.325 & 0.302 & 0.334 & 0.324 & 0.329 \\
\hline Spain & 0.058 & 0.113 & 0.194 & 0.376 & 0.541 & 0.776 & 0.715 & 0.763 & 0.613 & 0.825 & 0.452 & 0.385 & 0.717 \\
\hline Sweden & 0.017 & 0.137 & 0.171 & 0.842 & 0.360 & 0.436 & 0.361 & 0.694 & 0.464 & 0.188 & 0.229 & 0.245 & 0.299 \\
\hline United Kingdom & 0.092 & 0.105 & 0.208 & 0.359 & 0.334 & 0.393 & 0.432 & 0.464 & 0.441 & 0.448 & 0.652 & 0.651 & 0.603 \\
\hline
\end{tabular}

Source: own calculations based on the Eurostat (2018)

Due to the fact that the explained variable takes values from the interval $[0 ; 1]$ the logit transformation of the explanatory variable $G L_{j t}$ has been performed. The dependent variable was obtained in the form of logit $\ln \left[G L_{j t} /\left(1-G L_{j t}\right)\right]$, whose values belong to the range $(-\infty ; \infty)$. Thus, the possibility of obtaining the theoretical values of the $G L_{j t}$ index that exceed the allowed range $[0 ; 1]$ was eliminated. The indices of intra-industry trade were calculated for Poland's trade with individual EU countries, in the years 2004-2016, for three-digit product groups separated according to the Standard International Trade Classification. These groups were: 541 - medicinal and pharmaceutical products (other than medicaments of group 542 ) and 542 - medicaments (including veterinary medicaments). The study included 27 Polish trade partners who were members of the European Union in 2016. In order not to eliminate countries for which no intraindustry trade occurred in individual years, the procedure proposed by Lee and Lee (1993) was applied. It is based on the assumption that the explained variable (the Grubel-Lloyd index) instead of the value 0 , takes a very small value equal to 0.0000001 and on substitution of this value for logarithmic purposes. 


\section{Fig. 1: Intensity of intra-industry trade between Poland and European Union on the Grubel-Lloyd aggregate index}

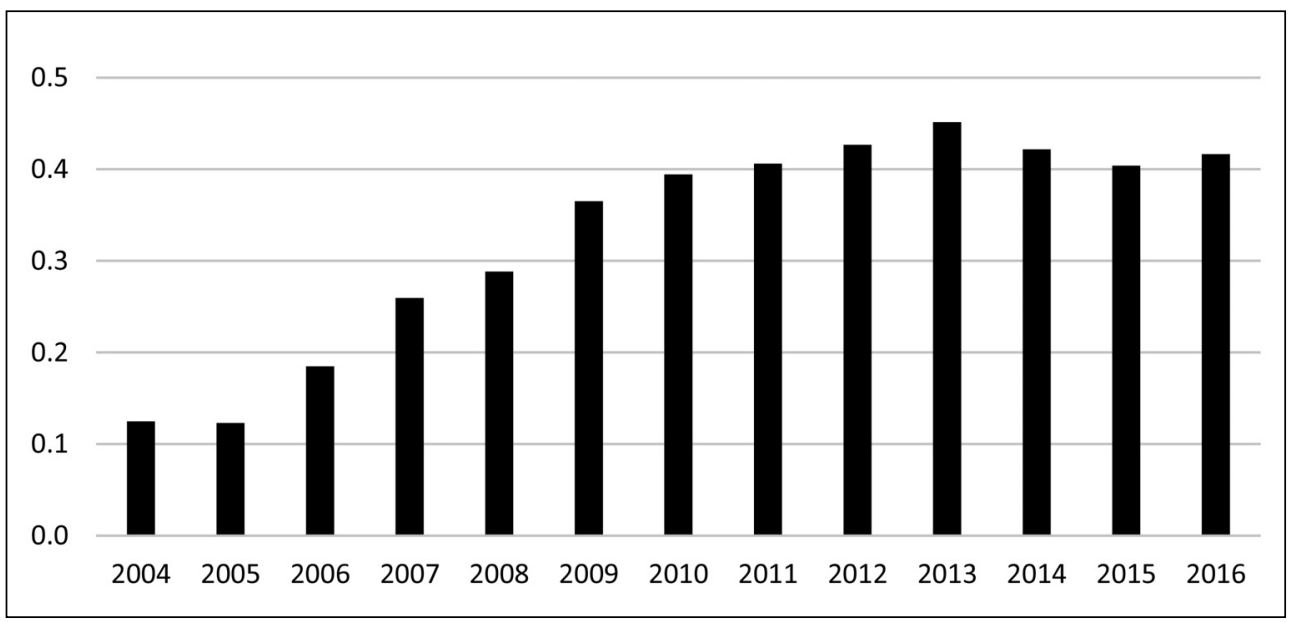

Source: own calculations based on the Eurostat (2018)

\section{Theoretical Hypotheses}

Based on theoretical literature and the results of previous empirical studies on countryspecific determinants of intra-industry trade, some research hypotheses $(\mathrm{H} 1-\mathrm{H} 8)$ have been formulated below. They focus on the characteristics of the economies of countries that are Poland's trading partners within the European Union. Due to the specificity of goods being subject to exchange, which in this case are pharmaceutical products, it was decided to formulate one hypothesis more (i.e., H9). The hypothesis $\mathrm{H} 9$ is not directly derived from the theory of intra-industry trade, however, in the context of the considerations regarding trade in pharmaceuticals, it seems to be justified. It concerns the category describing general government expenditure on health. It was assumed that this category of government spending significantly influences the intensity of intra-industry trade in pharmaceutical products.

The following research hypotheses concerning the intensity of intra-industry trade in pharmaceutical products between Poland and EU countries have been verified:

H1: The size of the economies of Poland's trade partners, measured by the size of their $G D P$, has a positive effect on the intensity of intra-industry trade with these partners in pharmaceutical products.

H2: There is a negative relationship between the relative differences in the size of the Polish economy and its trading partners' economies (measured by the size of GDP) and the intensity of intra-industry trade in pharmaceutical industry.

H3: The level of economic development of trade partners, measured by their GDP per capita, is positively correlated with the intensity of intra-industry trade with these partners in pharmaceutical products.

H4: There is a negative dependence between the relative differences in the level of economic development of Poland and its trading partners (measured by the size of GDP per capita) and the intensity of mutual intraindustry trade in pharmaceutical products.

H5: The intensity of intra-industry trade in Poland's bilateral trade in pharmaceutical products is positively correlated with the intensity of trade between the countries, measured by the share of the trading partner in Poland's trade in pharmaceutical industry products.

H6: The level of imbalance in Poland's bilateral trade in pharmaceutical products 
weakens the intensity of intra-industry trade in this kind of goods.

H7: There is a negative dependence between the geographical distance that separates trading partners and the intensity of their intra-industry trade.

H8: There is a positive dependence between the fact of having a common border with a trading partner and the intensity of intraindustry trade in pharmaceutical products.

H9: The size of general government expenditure on health incurred in trade partner countries has a positive impact on the intensity of intra-industry trade in pharmaceutical products between these partners.

The research hypotheses allowed model specification for panel data:

$$
\begin{aligned}
& \ln \left[G L_{j t} /\left(1-G L_{j t}\right)\right]=\alpha_{0}+ \\
& +\alpha_{1} \ln G D P_{j t}+\alpha_{2} \ln D i f f G D P_{j t}+ \\
& +\alpha_{3} \ln P C I_{j t}+\alpha_{4} \ln D i f f P C I_{j t}+ \\
& +\alpha_{5} \ln T I_{j t}+\alpha_{6} \ln T I M B_{j t}+ \\
& +\alpha_{7} \ln D I S T_{j}+\alpha_{8} \text { BOR }_{j}+ \\
& +\alpha_{9} \ln \text { EEALTH }_{j t}+v_{j t}
\end{aligned}
$$

$$
v_{j t}=e_{t}+u_{j}+\varepsilon_{j t}
$$

The description of individual variables and the sources of data used are presented in Tab. 2.

\section{Model Estimation}

Estimation of the panel data model, defined by the formula (3), was made using the Gretl programme (GNU Regression Econometrics Time-Series Library version 9.1.14.). Both the occurrence and significance of individual effects, as well as the nature of individual effects themselves (fixed or random) were not assumed a priori. The choice of the estimation method (pooled OLS, fixed effects, random effects) was made using the decision procedure proposed in the econometrics literature (see, among others Baltagi, 2001). Models with fixed and random effects were assessed and diagnostic tests were carried out. The results of the diagnostic tests are presented in Tab. 3 .

Based on the diagnostic tests carried

\begin{tabular}{|c|c|}
\hline Variables & Description of variables \\
\hline $\mathrm{GL}_{\mathrm{jt}}$ & $\begin{array}{l}\text { Intensity of intra-industry trade between Poland and the country } j \text { in the year } t \text {, } \\
\text { measured by the Grubel-Lloyd index. } \\
\text { Data source: Eurostat (2018), code: DS- } 018995 \text {. }\end{array}$ \\
\hline $\mathrm{GDP}_{\mathrm{jt}}$ & $\begin{array}{l}\text { Gross Domestic Product of the partner country } j \text {, in the year } t \text {. } \\
\text { Data source: Eurostat (2018), code: nama_10_gdp. }\end{array}$ \\
\hline DiffGDP $_{\mathrm{jt}}$ & $\begin{array}{l}\text { The index of the relative difference in the size of Poland's GDP and the trading } \\
\text { partner } j \text {, in the year } t \text {. The index values are determined by means of the following } \\
\text { formula (Zhang \& Li, 2006): } \\
\qquad \text { if f } G D P_{j t}=1+\frac{[w \ln w+(1-w) \ln (1-w)]}{\ln 2} \\
\qquad W=\frac{G D P_{P L t}}{G D P_{P L t}+G D P_{j t}} \\
\text { where: } \\
G D P_{P L}, G D P_{j t}-\text { gross domestic product of Poland and its trading partner } j \text { in the } \\
\text { year } t \text {. } \\
\text { The above index takes values from the interval [0;1]. If the differences in GDP } \\
\text { between countries are large, then the index approaches the value of } 1 \text {. With the } \\
\text { same GDP of both countries, the value is } 0 \text {. } \\
\text { Data source: Eurostat (2018), code: nama } 10 \text { gdp. }\end{array}$ \\
\hline
\end{tabular}
out, it was found that an appropriate model for studying the impact of macroeconomic determinants on the intensity of intra-industry trade is the fixed effects model (FE). Thus, the parameters of the fixed effects model

\section{Tab. 2: The variables used in empirical investigation (Part 1)}




\section{Tab. 2: The variables used in empirical investigation (Part 2)}

\begin{tabular}{|c|c|}
\hline $\mathrm{PCl}_{\mathrm{jt}}$ & $\begin{array}{l}\text { The variable representing the level of economic development of the trading partner } j \text {, } \\
\text { in the year } t \text {, expressed as GDP per capita. } \\
\text { Data source: Eurostat (2018), code: nama_10_pc. }\end{array}$ \\
\hline DiffPCl $_{\mathrm{jt}}$ & $\begin{array}{l}\text { The variable representing the distance in the level of economic development that } \\
\text { divides Poland and its trading partner } j \text {, in the year } t \text {. The values of the index are } \\
\text { measured using the following formula (Zhang \& Li, 2006): } \\
\quad \text { DiffPCI } I_{j t}=1+\frac{[w \ln w+(1-w) \ln (1-w)]}{\ln 2} \\
\quad w=\frac{P C I_{P L t}}{P C I_{P L t}+P C I_{j t}} \\
\text { where: } \\
P C I_{P L t} P C l_{j t}-\text { GDP per capita of Poland and its trading partner } j \text {, in the year } t \text {. } \\
\text { The above index takes values from the interval [0;1]. If the differences in per capita } \\
\text { income between countries are high, then the index approaches } 1 \text {. With the same } \\
\text { GDP per capita of both countries, the value is } 0 \text {. } \\
\text { Data source: Eurostat (2018), code: nama_10_pc. }\end{array}$ \\
\hline $\mathrm{Tl}_{\mathrm{jt}}$ & $\begin{array}{l}\text { The share of the country } j \text { in Poland's trade in pharmaceutical products, in the year } t \text {. } \\
\text { Data source: Eurostat (2018), code: DS-018995. }\end{array}$ \\
\hline TIMB $_{\mathrm{jt}}$ & $\begin{array}{l}\text { The degree of imbalance in trade between Poland and the country } j \text {, in the year } t \text {. } \\
\text { The variable is determined according to the below formula: } \\
\qquad T I M B_{j t}=\frac{\left|X_{j t}-M_{j t}\right|}{\left(X_{j t}+M_{j t}\right)} \\
\text { where: } \\
X_{j t} \text { - Polish exports to the country } j \text {, in the year } t \\
M_{j t}-\text { Polish imports to the country } j \text {, in the year } t \text {. } \\
\text { The } T I M B_{j t} \text { variable takes the value of } 0 \text {, if the trade between Poland and its trading } \\
\text { partner, in the year } t \text {, is balanced }\left(X_{j t}=M_{j t} \text { ) and takes the value of } 1 \text {, if in one of the }\right. \\
\text { countries, its exports or imports (but not both exports and imports at the same time) } \\
\text { is equal to } 0 \text {. } \\
\text { Data source: Eurostat (2018), code: DS- } 018995 \text {. }\end{array}$ \\
\hline DIST $_{j}$ & $\begin{array}{l}\text { Geographical distance, measured in kilometres, between the capital cities of Poland } \\
\text { and its trading partner } j \text {. } \\
\text { Data source: Centre D'Etudes Prospectives et D'Informations Internationales } \\
(2018) \text {. }\end{array}$ \\
\hline $\mathrm{BOR}_{\mathrm{j}}$ & $\begin{array}{l}\text { Dummy variable, takes the value of } 1 \text {, if Poland has a common border with a trading } \\
\text { partner } j \text { and the value of } 0 \text {, if it does not border with the trading partner } j .\end{array}$ \\
\hline $\mathrm{HEALTH}_{\mathrm{jt}}$ & $\begin{array}{l}\text { General government expenditure on health incurred by the country of the trade } \\
\text { partner } j \text {, in the year } t \text {. } \\
\text { Data source: Eurostat (2018), code: gov_10a_exp_COFOG_GF07. }\end{array}$ \\
\hline $\mathrm{v}_{\mathrm{jt}}$ & $\begin{array}{l}\text { Random error in the object } j \text {, in the time period } t \text {, which consists of the following } \\
\text { components: } \\
e_{t}-\text { impulses affecting all observations in the period } t \\
u_{j}-\text { impulses affecting all observations in the object } j, \\
\varepsilon_{j t}-\text { impulses affecting only observations in the object } j \text {, in the period } t \text {. }\end{array}$ \\
\hline
\end{tabular}


Tab. 3: $\begin{aligned} & \text { Test statistics and significance levels in the diagnostic tests of the model } \\ & \text { of intra-industry trade in pharmaceuticals between Poland and EU countries }\end{aligned}$

\begin{tabular}{l|c|c}
\multicolumn{1}{c|}{ Diagnostic test } & Test statistic & p-value \\
\hline Wald test & $\mathrm{F}=8.46793$ & $<0.00001$ \\
\hline Breusch-Pagan test & $\mathrm{LM}=156.423$ & $<0.00001$ \\
\hline Hausman test & $\mathrm{H}=25.3214$ & $<0.00001$ \\
\hline
\end{tabular}

were estimated. However, a phenomenon of heteroscedasticity occurred, i.e. heterogeneity of variances of random components within the sample. Heteroscedasticity affects the incorrect estimation of standard errors for individual parameters and overestimation of the determination coefficient, which may distort the conclusions drawn on the significance of variables. Therefore, ultimately, the Weighted Least Squares (WLS) method was used to estimate the parameters, where the weights were the inverse of the elements from the variance of random components estimated for individual units in the panel.

\section{Results of Estimation and Discussion of Findings}

Values of statistically significant parameters of the model described by the formula (3) are presented in Tab. 4.

The model is correct in statistical terms. Five of the nine potential explanatory variables turned out to be significant. The general performance of the model is satisfactory (Adjusted $\mathrm{R}^{2}=0.693769$ ).

When interpreting the results obtained, you can use the following interpretation method in relation to the variables that were previously logarithmized: an increase in the explanatory variable by $1 \%$ causes, ceteris

\begin{tabular}{|c|c|c|c|c|c|}
\hline $\begin{array}{ll}\text { Tab. 4: } & \text { The } \\
\text { of in }\end{array}$ & $\begin{array}{l}\text { s of estimation } \\
\text { dustry trade in }\end{array}$ & $\begin{array}{l}\text { of the mode } \\
\text { harmaceuti }\end{array}$ & cribing th & terminants & \\
\hline & & $\begin{array}{l}\text { Dependent va } \\
\operatorname{In}\left[G L_{j l} /(1-G\right.\end{array}$ & & & \\
\hline $\begin{array}{c}\text { Independent } \\
\text { variables }\end{array}$ & Coefficient & Std. Error & t-ratio & p-value & Significance \\
\hline Constant & 2.9795100 & 1.0755700 & 2.770 & 0.00590 & $* * *$ \\
\hline$P C l_{j t}$ & -0.6340501 & 0.1238950 & -5.118 & $<0.00001$ & $* * *$ \\
\hline DiffPCl $_{j t}$ & -0.0359025 & 0.0158606 & -2.264 & 0.02420 & ** \\
\hline$T l_{j t}$ & 0.1717640 & 0.0534901 & 3.211 & 0.00140 & $* * *$ \\
\hline$T I M B_{j t}$ & -1.7156300 & 0.0751459 & -22.830 & $<0.00001$ & *** \\
\hline$H_{E A L T H_{j t}}$ & 0.2079440 & 0.0562981 & 3.694 & 0.00030 & $* * *$ \\
\hline Obs & ions & & 35 & & \\
\hline Standard e & f residuals & & 0.90 & & \\
\hline & & & 0.698 & & \\
\hline Adj & $R^{2}$ & & 0.69 & & \\
\hline$F(5,34$ & 59.5853 & & -value for tes & $<0.00001$ & \\
\hline
\end{tabular}

Source: own calculations

Note: ** Statistically significant at $5 \%,{ }^{* * *}$ significant at $1 \%$ 
paribus, an increase or decrease (depending on the sign of the parameter) of the explained variable by $\alpha \%$ (a parameter located at a given variable explanatory). In this case, the logit is the explained variable, which means that the relation $G L_{j l} /\left(1-G L_{j t}\right)$, which is the index of intraindustry trade $\left(G L_{j t}\right)$ and inter-industry trade $\left(1-G L_{j t}\right)$ changes by $\alpha \%$.

The size of GDP per capita achieved in the countries of Poland's trading partners turned out to be a variable that significantly and negatively impacts the intensity of intraindustry trade. This variable represents the level of economic development of individual countries. The research carried out shows that, on average, GDP growth per capita in trading partners' countries by $1 \%$ causes a decrease that is less than proportional (by about $0.6 \%$ ) in the ratio of intra-industry to inter-industry trade in pharmaceutical products. The results obtained with regard to this variable - this is the direction of the impact, do not confirm the predictions of the theory of intra-industry trade, according to which higher per capita income facilitates intense intra-industry exchange (see hypothesis $\mathrm{H} 3$ ). Therefore, it is worth making an attempt to explain this relationship in the context of trade in pharmaceutical products.

In the theory of intra-industry trade, the impact of the GDP per capita variable on the intensity of intra-industry trade is considered on the demand and supply side (Czarny, 2002). In the first case, it is indicated that along with the increase in consumer incomes, their willingness to purchase differentiated products increases, they often buy many variants of varied goods or are willing to pay more for the preferred option, best suited to their expectations. This behaviour of consumers, i.e., the demand for goods differentiated at the aggregate level, facilitates the development of intra-industry trade. It is worth noting, however, that pharmaceutical products are specific goods purchased by consumers in strictly defined situations resulting from the needs of protecting their health or even lives.

Therefore, in this particular situation, the result obtained (the negative impact of the $P C l_{j t}$ variable on the intensity of intra-industry turnover of pharmaceutical products) may be justified. In the case of pharmaceutical products, taking (consuming) by the final consumer (patient) many variants of a particular good (pharmaceutical products) is unjustified and even harmful from a medical point of view. Thus, customers (patients) generally do not report additional demand for further variants of the pharmaceutical product along with an increase in income. An exception in this case may be pharmaceutical products being dietary supplements.

The negative impact of the $P C l_{j t}$ variable can also be explained by analysing the phenomenon from the supply side. Interpretation then refers to the resources of production factors in trading countries. Rich countries with a significant GDP per capita have large capital resources, which allows the development of high technology industries, which undoubtedly include the pharmaceutical industry. A country's welldeveloped pharmaceutical industry produces, apart from relatively simple preparations, also the most modern drugs. It is therefore possible to develop exports, especially of technologically advanced drugs, to countries that do not produce them. Therefore, less affluent countries can offer simple, less technologically advanced drugs on the market, which can be produced without the need to possess or buy licenses, so these are more often generic drugs. However, it should be noted that these drugs, i.e. simple ones, are also produced by the pharmaceutical industry in richer countries, sometimes even cheaper due to the disclosure of the economies of scale. Therefore, there is no need to import them from other countries, and this certainly is not conducive to the development of intraindustry trade.

The confirmation of the above reasoning may be the results obtained with respect to the $D_{\text {iffPCl }}$ variable. The research findings show that in trade in pharmaceutical products, the relative differences in the level of economic development of Poland and its trading partners limit the development of mutual intra-industry trade. The parameter $\alpha$ at the DiffPCl ${ }_{j t}$ variable was -0.0359025 . Thus, the hypothesis $\mathrm{H} 4$ was positively verified.

The results of the study confirm that the factor that significantly and also positively affects the growth of intra-industry trade indices is the degree of trade intensity between Poland and its trading partners (the $T I_{j t}$ variable). The intensity of trade was expressed in the share of individual trade partners in Poland's total trade in pharmaceutical products. The obtained value of the parameter $\alpha$ at the variable $T I_{j t}$ informs that, on average, the increase in the intensity 
of trade between countries by $1 \%$ results in an increase of intra-industry trade in relation to inter-industry trade by over $0.17 \%$. Therefore, the research hypothesis H5 was positively verified.

The factor that significantly but at the same time negatively impacts the intensity of intra-industry trade is the degree of imbalance in trade between pharmaceutical products between Poland and the European Union. A significant impact of this variable was to be expected because in a situation when trade between two countries is not balanced, the Grubel-Lloyd index cannot reach the maximum value. The parameter $\alpha$ at the $T I M B_{j t}$ variable was -1.71563 . The hypothesis $\mathrm{H} 6$ was positively verified.

General government expenditure on health in the country of the trade partner was a statistically significant factor influencing the intensity of intraindustry trade in Poland's trade in pharmaceutical products. This variable was included in the model deliberately, due to the specifics of the analysed goods. Pharmaceutical products serve to protect health and life. The study confirms that increasing government expenditure on health in the trade partner country has a positive impact on the intensity of intra-industry trade with this country $(\alpha=0.207944)$. With reference to the variable $H E A L T H_{j t}$, the sign which was obtained was consistent with the assumption made in the hypothesis $\mathrm{H} 9$, which allowed for its positive verification.

The variables related to the size of the economies of trade partners $\left(G D P_{j t}\right.$ and DiffGDP $P_{j t}$ ) were proved to be statistically insignificant. Therefore, the $\mathrm{H} 1$ hypothesis, according to which intra-industry trade is more intense in trade with large countries that have a larger GDP, could not be verified. The $\mathrm{H} 2$ hypothesis, according to which the larger relative differences in the size of economies - of Poland and its trading partners, the less intense intra-industry exchange, could not be verified, either. The $D I S T_{j}$ and $B O R_{j}$ variables were also statistically insignificant. This means that the $\mathrm{H} 7$ hypothesis, which assumed a negative dependence between the geographical distance that separates trading partners and the intensity of their intra-industry exchange, and the $\mathrm{H} 8$ hypothesis, according to which the intra-industry trade develops better if the countries are close neighbours, i.e. they have a common border, were not verified.

\section{Conclusions}

One of the manifestations of the ongoing cooperation of countries is the intensification of mutual intra-industry trade understood as parallel import and export of similar products belonging to the same industry (commodity group). This paper identified the factors determining intra-industry trade in pharmaceutical products between Poland and European Union countries. The focus is on factors that relate to the characteristics of the trading partner economies, i.e. the so-called country-specific determinants. In the case of pharmaceutical products, the factors that related to the level of economic development of trading partners were statistically significant. However, the research shows that the level of economic development of EU member states (measured by the size of their GDP per capita) is not conducive to the development of intraindustry trade. The direction of the influence of this variable on the development of intraindustry trade obtained in this study does not confirm the predictions of the theory of intraindustry trade. However, the negative impact of this factor can be explained by the specificity of pharmaceutical products. These products do not belong to the category of goods for which customers report greater demand when their revenue increases. Since it is not medically justifiable, they do not want to buy many variants of specific pharmaceutical products, as it usually happens in the case of other goods, e.g. in the case of clothing.

The impact of the variable describing the relative differences in the level of economic development of Poland and its trading partners on the intensity of mutual intra-industry trade is in contrast with the predictions of the theory. The research shows that the degree of the intensity of trade in pharmaceutical products between Poland and its trading partners also has an important and positive impact on the development of intra-industry trade. On the other hand, however, the degree of imbalance in trade in pharmaceutical products between Poland and EU countries has a negative impact. The obtained results of the research also confirm that an important factor that positively influences the development of intra-industry trade in pharmaceutical products is the size of general government expenditure on health in the country of the trade partner. The variables related to the size of the trading partners' 
economies, the geographical distance between Poland and its trading partners, and the fact that Poland has a common border with some trade partners turned out to be statistically nonsignificant factors.

The model of intra-industry trade constructed in this study can be used to identify countries (within the European Union) which have potential for the development of trade in the field of pharmaceutical products. In this context, particular attention should be paid to those trading partners with whom trade in pharmaceuticals is relatively large and intratrade indicators remain at a low level.

This study is part of the research stream that has been undertaken in world science. However, it certainly does not exhaust the problem. In terms of the presented issue, it is worth examining the impact of identified determinants separately on vertical intraindustry trade and separately on horizontal intra-industry trade. Particularly interesting in this context could also be in-depth analyses of the impact of foreign direct investment (broken down into the vertical and horizontal forms) on intra-industry trade.

The paper was supported by the research project "Positive social change in an organization as a factor of a company engagement in sustainable development". The project was funded by the National Science Centre, Poland, on the decision number DEC2017/25/B/HS4/01113.

\section{References}

Aghlmand, S., Rahimi, B., FarrokhEslamlou, H., Nabilou, B., \& Yusefzadeh, H. (2018). Determinants of Iran's Bilateral IntraIndustry Trade in Pharmaceutical Industry. Iranian Journal of Pharmaceutical Research, 17(2), 822-828.

Ambroziak, Ł. (2016). FDI and Intraindustry Trade in the Automotive Industry in the New EU Member States. International Journal of Management and Economics, 52(1), 23-42. https://dx.doi.org/10.1515/ijme-2016-0025.

Anderson, J. E. (1979). A Theoretical Foundation for the Gravity Equation. American Economic Review, 69(1), 106-116.

Balassa, B. (1966). Tariff Reductions and Trade in Manufactures Among the Industrial Countries. The American Economic Review, $56,466-473$.
Baltagi, B. H. (2001). Econometric Analysis of Panel Data. Chichester, John Wiley \& Sons Ltd.

Bergstrand, J. H. (1985). The Gravity Equation in International Trade: Some Microeconomic Foundations and Empirical Evidence. Review of Economics and Statistics, 67(3), 474-481. https://dx.doi. org/10.2307/1925976.

Bergstrand, J. H. (1990). The HeckscherOhlin-Samuelson Model, the Linder hypothesis and the determinants of bilateral intra-industry trade. The Economic Journal, 100, 1216-1229. https://dx.doi.org/10.2307/2233969.

Brander, J. A. (1981). Intra-Industry Trade in Identical Commodities. Journal of International Economics, 11(1), 1-14. https://dx.doi.org/10.1016/0022-1996(81)90041-6.

Caetano, J., \& Galego, A. (2007). In search for the Determinants of Intra-Industry Trade within an Enlarged Europe. South-Eastern Europe Journal of Economics, 2, 163-183.

Centre D'Etudes Prospectives et D'Informations Internationales. (2018). GeoDist Database. Retrieved from http://www.cepii.fr/ cepii/en/bdd_modele/bdd.asp.

Cheba, K., \& Szopik-Depczyńska, K. (2017). Multidimensional comparative analysis of the competitive capacity of the European Union countries and geographical regions. Oeconomia Copernicana, 8(4), 487-504. https://doi.org/10.24136/oc.v8i4.30.

Cieślik, A., \& Michałek, J. (2018). Process and product innovations, multi-product status and export performance: firm-level evidence from V-4 countries. Equilibrium. Quarterly Journal of Economics and Economic Policy, 13(2), 233-250. https://doi.org/10.24136/eq.2018.012.

Cieślik, A., \& Wincenciak, L. (2018). Intraindustry trade in differentiated and homogenous commodities: Brander and Krugman models unified. Equilibrium. Quarterly Journal of Economics and Economic Policy, 13(1), 29-53. https://dx.doi.org/10.241136/eq.2018.002.

Czarny, E. (2002). Teoria i praktyka handlu wewnątrzgałęziowego. Warszawa: Oficyna Wydawnicza Szkoły Głównej Handlowej.

Dalgin, M. H. (2010). Intra- vs. InterIndustry Trade: Do Country Differences Matter? International Research Journal of Finance and Economics, 56, 29-41.

Davis, D. R. (1995). Intra-Industry Trade: A Heckscher-Ohlin-Ricardo Approach. Journal of International Economics, 39(3-4), 201-226. https://doi.org/10.1016/0022-1996(95)01383-3. 
Ekanayake, E. M. (2001). Determinants of Intra-Industry Trade: The Case of Mexico. The International Trade Journal, 15(1), 89-112. https://doi.org/10.1080/088539001300005468.

European Commission. (2014). Pharmaceutical Industry: A Strategic Sector for the European Economy. Retrieved from http://ec.europa.eu/DocsRoom/documents/7649.

Eurostat. (2018). Database. EU trade since1988 by SITC. Retrieved from https://ec.europa.eu/eurostat/data/database.

Foster, N., \& Stehrer, R. (2011). Preferential Trade Agreements and the Structure of International Trade. Review of World Economics, 147(3), 385-409. https://doi. org/10.1007/s10290-011-0093-y.

Fukao, K., Ishido, H., \& Ito, K. (2003). Vertical intra-industry trade and foreign direct investment in East Asia. Journal of the Japanese and International Economics, 17(4), 468-506. https://doi.org/10.1016/j.jjie.2003.09.004.

Grubel, H. G., \& Lloyd, P. J. (1975). IntraIndustry Trade: The Theory and Measurement of International Trade in Differentiated Products. London: Macmillan.

Helpman, E. (1987). Imperfect Competition and International Trade: Evidence from Fourteen Industrial Countries. Journal of the Japanese and International Economies, 1(1), 62-81. https://doi.org/10.1016/08891583(87)90027-X.

Hummels, D., \& Levinsohn, J. (1995). Monopolistic Competition and International Trade: Reconsidering the Evidence. The Quarterly Journal of Economics, 110(3), 799-836. https://doi.org/10.2307/2946700.

Jámbor, A. (2014). Determinants of IntraIndustry agri-food trade in the Visegrad countries. Acta Alimentaria, 43(2), 246-253. https://doi.org/10.1556/AAlim.43.2014.2.8.

Kocmanová, A., Dohnal, M., \& Meluzín, T. (2011). Qualitative Equationless Models as Simple Integrators of Vague Sustainability Knowledge Items. Transformations in Business \& Economics, 11(3), 187-196.

Krugman, P. R. (1979). Increasing Returns Monopolistic Competition, and International Trade. Journal of International Economics, 9(4), 469-479. https://doi.org/10.1016/00221996(79)90017-5.

Lee, H.-H., \& Lee, Y.-Y. (1993). IntraIndustry Trade in Manufactures: The Case of Korea. Weltwirtschaftliches Archiv, 129(1), 159-171.
Leitão, N. C. (2011). Intra-industry trade in the agriculture sector: The experience of United States. African Journal of Agricultural Research, 6(1), 186-190. https://doi.org/10.5897/ AJAR10.822.

Leitão, N. C., \& Shahbaz, M. (2012), Liberalization and United States' Intra-Industry Trade. International Journal of Economics and Financial Issues, 2(4), 505-512.

Linder, S. B. (1961). An Essay on Trade and Transformation. Stockholm: John Wiley \& Sons Ltd.

Loertscher, R., \& Wolter, F. (1980). Determinants of intra-industry trade: Among countries and across industries. Weltwirtschaftliches Archiv, 116(2), 280-293.

Łapińska, J. (2014). Determinants of Intraindustry Trade in Agricultural and Food Products between Poland and EU Countries. Danube: Law and Economics Review, 5(3), 159-172. https://doi.org/10.2478/danb-2014-0009.

Łapińska, J. (2015). The economic integration as a determinant of intra-industry trade: the case of Poland. Scientific Papers of the University of Pardubice, 22(33), 77-87.

Łapińska, J. (2016). Determinant factors of intra-industry trade: the case of Poland and its European Union trading partners. Equilibrium. Quarterly Journal of Economics and Economic Policy, 11(2), 251-264. https://doi.org/10.12775/ EQUIL.2016.011.

Markusen, J. R., \& Vanables, A. J. (1996). The Theory of Endowment, Intra-Industry and Multinational Trade [NBER Working Paper No. 5529]. Retrieved from http://www.nber.org/ papers/w5529.pdf?new_window=1.

Matthews, K. (1998). Intra-Industry Trade: An Australian Panel Study. Journal of Economic Studies, 25(2), 84-97. https://doi. org/10.1108/01443589810202094.

Meluzín, T., \& Zinecker, M. (2014). Reasons for IPO Implementation: Empirical Evidence from the Polish Capital Market. Engineering Economics, 25(3), 294-301. https://doi. org/10.5755/j01.ee.25.3.3529.

Meluzín, T., Pietrzak, M. B., Balcerzak, A. P., Zinecker, M., Doubravský, K., \& Dohnal, M. (2017). Rumours Related to Political Instability and their Impact on IPOs: The Use of Qualitative Modeling with Incomplete Knowledge. Polish Journal of Management Studies, 16(2), 171-187. https://doi.org/10.17512/pjms.2017.16.2.15.

Nazarczuk, J. M., \& Umiński, S. (2018). The Impact of Special Economic Zones on Export 
Behaviour. Evidence from Polish Firm-Level Data. E\&M Ekonomie a Management, 21(3), 4-21. https://doi.org/10.15240/tul/001/2018-3-001.

Okubo, T. (2007). Intra-Industry Trade, Reconsidered: The Role of Technology Transfer and Foreign Direct Investment. The World Economy, 30(12), 1855-1876. https://doi. org/10.1111/j.1467-9701.2007.01073.x.

Onogwu, G. O. (2013). Regional Characteristics Effects on Intra-Industry Trade in Residues and Wastes from Food Mill Industry. Journal of Agriculture and Sustainability, 3(1), 108-121.

Phan, H. T., \& Jeong, Y. J. (2014). An empirical analysis of intra industry trade in manufactures between Korea and ASEAN. Journal of Economic Studies, 41(6), 833-848. https://doi.org/10.1108/JES-01-2013-0006.

Pietrzak, M. B., \& Łapińska, J. (2014). Zastosowanie modelu grawitacji do identyfikacji czynników determinujących przepływy handlowe w Unii Europejskiej. Przegląd Statystyczny, 61(1), 65-77.

Pietrzak, M. B., \& Łapińska, J. (2015). Determinants of the European Union's trade: evidence from a panel estimation of the gravity model. E\&M Ekonomie a Management, 18(1), 18-27. https://doi.org/10.15240/tul/001/2015-1-002.

Sharma, K. (2004). Horizontal and vertical intra-industry trade in Australian manufacturing: does trade liberalization have any impact? Applied Economics, 36, 1723-1730. https://doi. org/10.1080/000368404200018534.

Szczepaniak, I. (2018). Comparative advantages in Polish export to the European Union - food products vs selected groups of non-food products. Oeconomia Copernicana, 9(2), 287-308. https://doi.org/10.24136/oc.2018.015.

Thorpe, M., \& Zhang, Z. (2005). Study of the Measurement and Determinants of IntraIndustry Trade in East Asia. Asian Economic Journal, 19(2), 231-247. https://doi.org/10.1111/ j.1467-8381.2005.00211.x.

Wakasugi, R. (2007). Vertical Intra-Industry Trade and Economic Integration in East Asia. Asian Economic Papers, 6(1), 26-39. https://doi.org/10.1162/asep.2007.6.1.26.

Xing, Y. (2007). Foreign direct investment and China's bilateral intra-industry trade with Japan and the US. Journal of Asian Economics, 18(4), 685-700. https://doi.org/10.1016/j. asieco.2007.03.011.

Yusefzadeh, H., Hadian, M., Gorji, H. A., \& Ghaderi, H. (2015). Assessing the Factors Associated with Iran's Intra-Industry trade in Pharmaceuticals. Global Journal of Health Science, 7(5), 311-319. https://doi.org/10.5539/ gjhs.v7n5p311.

Zhang, Z., \& Li, C. (2006). Country-Specific Factors and the Pattern of Intra-Industry Trade in China's Manufacturing. Journal of International Development, 18(8), 1137-1149. https://doi.org/10.1002/jid.1288.

doc. Justyna Łapińska, Ph.D. Nicolaus Copernicus University in Torun Faculty of Economics and Management Poland justlap@umk.pl

Ing. Jana Meluzínová, Ph.D. Jan Evangelista Purkyně University in Ústí nad Labem

Faculty of Social and Economic Studies Czech Republic jana.meluzinova@ujep.cz

Ing. Jiří Uhman Jan Evangelista Purkyně University in Ústí nad Labem

Faculty of Social and Economic Studies

Czech Republic jiri.uhman@ujep.cz 


\title{
Abstract
}

\section{COUNTRY-SPECIFIC DETERMINANTS OF INTRA-INDUSTRY TRADE IN PHARMACEUTICALS: THE CASE OF POLAND AND ITS EUROPEAN UNION PARTNERS}

\author{
Justyna Łapińska, Jana Meluzínová, Jiří Uhman
}

Trade cooperation between European Union countries is based mainly on intra-industry trade, consisting in the simultaneous import and export of similar products belonging to the same industry (commodity group).

The present study has investigated the country-specific determinants of intra-industry trade between Poland and its European Union trading partners in pharmaceutical products during the time period 2004-2016. To this end, an econometric model for panel data was constructed.

The research shows that the intensity of intra-industry trade in Poland-EU trade in pharmaceuticals is determined by several key factors. The intensity of trade with particular EU countries and the size of general government expenditure on health in the countries of trading partners have a positive impact on the development of this type of exchange. A factor that significantly and simultaneously affects the intensity of intra-industry trade is the degree of imbalance in the trade balance in pharmaceutical products with individual trading partners.

The development of intra-industry trade is also limited by factors related to the level of economic development of trading partners. The study confirmed that the greater the differences in the level of GDP per capita between Poland and the trading partner, the less intense intra-industry trade. Also, the growth of GDP per capita in the countries of trade partners is not conducive to the development of intra-industry trade in Poland's trade in pharmaceuticals. The direction of the impact of this variable (GDP per capita) on the intensity of two-way trade obtained in this study does not confirm the predictions of the theory of intra-industry trade. However, the negative impact of this factor can be explained by the specificity of pharmaceutical products that are purchased by consumers generally only in justified situations resulting from health or life protection.

Key Words: Intra-industry trade, pharmaceutical products, Poland, European Union.

JEL Classification: F12, F14.

DOI: 10.15240/tul/001/2019-2-013 